\title{
PENGARUH PEMBERIAN SUP JAMUR TIRAM PUTIH (Pleurotus Ostreatus) TERHADAP KADAR KOLESTEROL TOTAL SUBJEK OBESITAS
}

\author{
Afiah, Hesti Murwani Rahayuningsih") \\ Program Studi Ilmu Gizi Fakultas Kedokteran Universitas Diponegoro \\ J1.Dr.Sutomo No.18, Semarang, Telp (024) 8453708, Email : gizifk@undip.ac.id
}

\begin{abstract}
Background: Central obesity was associated with increased LDL cholesterol (low density lipoprotein), VLDL (very low density lipoprotein) and triglycerides; and decreased in HDL cholesterol (high density lipoprotein). Hypercholesterolemia was a lipoprotein metabolic disorder characterized by high LDL levels and cholesterol. Hypercholesterolemia wasstrong risk factorcoronary heart disease and metabolic syndrome. White oyster mushrooms contains beta-glucanwhich dietary fiber that had character as hypocholesterolemic. This study aimed to determine the effect of white oyster mushroom soup (Pleurotusostreatus) on total cholesterol levels in obesity subjects.

Method : This research waspre-experiment with one group pre test - post test. Subjectswere 15 obese men and women with total cholesterol levels of 200-239 mg/dl. Subjects received $1.21 \mathrm{~g} / \mathrm{kg} /$ day of white oyster mushroom soup for 21 days. Analysis of total cholesterol level used CHOD-PAP method and blood was taken after the subjects fasted for 10 hours. Normality test used the Shapiro Wilk, statistical analysis used the wilcoxon.

Results: Median of total cholesterol level of subjects before intervention was $226 \mathrm{mg} / \mathrm{dl}$. Media of total cholesterol level after interventionwas $189 \mathrm{mg} / \mathrm{dl}$. Consumption of white oyster mushroom soup with a dose of $1.21 \mathrm{~g} / \mathrm{kg} / \mathrm{day}$ for 21 days showed a significant lowering total cholesterol levels $(p=0.001)$.

Conclusion: Consumption of white oyster mushroom soup decrease on total cholesterol levels in obesity subjects.

Keyword : oyster mushroom; beta glucan; hypercholesterolemic; obesity
\end{abstract}

\begin{abstract}
ABSTRAK
LatarBelakang : Obesitas terutama obesitas sentral berhubungan dengan meningkatnya kolesterol LDL (low density lipoprotein), VLDL (very low density lipoprotein) dan trigliserida; dan penurunan kolesterol HDL (high density lipoprotein). Hiperkolesterolemia merupakan gangguan metabolik lipoprotein yang ditandai dengan tingginya kadar LDL dan kolesterol merupakan faktor yang mendorong terjadinya jantung koroner dan sindroma metabolik. Jamur tiram putih mengandung serat pangan beta glukan yang memiliki sifat hipokolesterolemik. Penelitian ini bertujuan untuk mengetahui pengaruh pemberian sup jamur tiram putih (Pleurotus Ostreatus) terhadap kadar kolesterol total pada subjek obesitas.

Metode :Jenis penelitian adalah pre experiment dengan rancangan one group pre test - post test. Subjek adalah 15 pria dan wanita obesitas dengan kadar kolesterol total 200-239 mg/dl. Subjek mendapat 1,21 g/kgbb/hari jamur tiram putih dalam bentuk sup jamur tiram putih selama 21 hari. Analisis kadar kolesterol total menggunakan metode CHOD-PAP, darah diambil setelah subjek berpuasa selama 10 jam. Uji normalitas menggunakan Shapiro Wilk. Analisis statistic menggunakan uji wilcoxon.

Hasil : Nilai tengah kadar kolesterol total subjek sebelum intervensi yaitu 226 mg/dl. Nilai tengah kadar kolesterol total setelah intervensi yaitu $189 \mathrm{mg} / \mathrm{dl}$. Konsumsi sup jamur tiram putih dengan dosisl,21 g/kgbb/hari selama 21 hari secara signifikan berpengaruh terhadap penurunan kadar kolesterol total ( $p=0,001)$.

Kesimpulan : Konsumsi sup jamur tiram putih berpengaruh terhadap penurunan kadar kolesterol total pada subjek obesitas.
\end{abstract}

Kata kunci : jamur tiram putih; beta glukan; hiperkolesterolemia; obesitas

\section{PENDAHULUAN}

Obesitas merupakan masalah kesehatan kronik yang sekarang dikenal sebagai new world syndrom. Penyebaran obesitas hampir terjadi diberbagai negara diseluruh dunia sehingga disebut sebagai epidemik global. ${ }^{1,2}$ Kejadian obesitas mengalami peningkatan dari tahun ke tahun khususnya di Indonesia. Prevalensi obesitas di Indonesia tahun 2013 pada pria dewasa (> 18 tahun) sebanyak $19,7 \%$ mengalami peningkatan dari tahun $2010(7,8 \%)$. Sedangkan pada wanita dewasa (>18 tahun) sebanyak 32,9 \% mengalami kenaikan $17,5 \%$ dari tahun $2010 .^{3}$

Obesitas merupakan kelebihan akumulasi energi dalam bentuk lemak tubuh yang disebabkan oleh tidakseimbangnya asupan dan pengeluaran kalori. Kelebihan lemak tubuh dapat terjadi dilemak subkutan (obeitas general) dan lemak viseral (obesitas sentral). ${ }^{4}$ Obesitas sentral berhubungan dengan meningkatnya kolesterol LDL (low density lipoprotein), VLDL (very low density lipoprotein) dan trigliserida; dan 
penurunan kolesterol HDL (high density lipoprotein). ${ }^{5}$

Kadar kolesterol kategori batas atas berkisar antara 200-239 mg/dl. ${ }^{6}$ Seseorang yang memiliki kadar kolesterol batas atas akan dengan mudah berkembang menjadi hiperkolesterolemia apabila tidak dilakukan terapi penurunan kadar kolesterol. Hiperkolesterolemia merupakan gangguan metabolik lipoprotein yang ditandai dengan tingginya kadar LDL dan kolesterol. ${ }^{7}$

Usia 40-50 tahun merupakan usia dimana terjadi peningkatan kadar kolesterol total. Peningkatan kadar kolesterol diyakini merupakan faktor yang mendorong terjadinya jantung koroner dan sindroma metabolik. ${ }^{8,9}$ Faktor keturunan, makanan dan lingkungan berperan dalam menentukan kadar kolesterol seseorang. Faktor asupan seperti konsumsi secara terus menerus lemak jenuh dan kolesterol dalam jumlah tinggi dipercayai secara langsung berhubungan dengan hiperkolesterolemia. ${ }^{7}$ Peningkatan asupan asam lemak jenuh dan simpanan lemak yang berlebihan dapat menyebabkan peningkatan kadar kolesterol terutama pada orang yang mengalami obesitas sentral. $^{8}$

Modifikasi asupan makanan dan gaya hidup seperti konsumsi makanan tinggi serat,rendah lemak jenuh, peningkatan aktivitas fisik dan olahraga merupakan cara yang dapat digunakan untuk menurunkan kadar kolesterol.7,10 Pengurangan asupan lemak dan mengganti lemak jenuh dan lemak trans dengan lemak tak jenuh, pembatasan asupan kolesterol dan peningkatan asupan serat dapat menurunkan kadar kolesterol total, kolesterol LDL dan trigliserida. ${ }^{11}$ Modifikasi diet rendah lemak yang direkomendasikan adalah dengan mengkonsumsi 25-40 gram serat makanan yang meliputi sedikitnya 7-13 gram serat larut untuk memperbaiki profil lipid selama 3 minggu. ${ }^{12}$

Jamur tiram putih atau Pleurotus ostreatus merupakan makanan yang cukup populer di masyarakat karena mudah dibudidayakan dan diolah. Jamur tiram putih mengandung serat pangan yang memiliki sifat hipokolesterolemik. ${ }^{14}$ Serat pangan $\beta$-glukan merupakan serat larut yang dapat menigkatkan rasa kenyang yang berhubungan dengan penurunan Indek Massa Tubuh (IMT), kolesterol darah dan respon postprandial glukosa. Serat larut dapat meningkatkan masa feses dan sebagai agen penurunan kolesterol pada pasien yang menderita moderate hiperkolesterolemia. ${ }^{15}$

Penelitian terdahulu yang dilakukan pada remaja dengan hiperlipidemia, diperoleh hasil bahwa pemberian 300 gram jamur tiram putih dalam bentuk sup selama 21 hari mampu menurunkan kadar trigliserida, LDL teroksidasi, dan kolesterol total secara bermakna. ${ }^{13}$ Penelitian mengenai efek antihiperkolesterol ekstrak alkali $\beta$ glukan jamur tiram putih pada hamster selama 2 minggu dapat menurunkan kadar kolesterol total dan LDL secara signifikan dengan dosis $50,4 \mathrm{~g} / \mathrm{kg}$ $\mathrm{bb}$ atau setara dengan $0,11 \mathrm{~g} / \mathrm{kg}$ bb setelah dikonversikan untuk perhitungan pada manusia. ${ }^{18}$ Asupan serat larut yang direkomendasikan untuk memperbaiki profil lipid sebanyak 7-13 gram. ${ }^{12}$ Jamur tiram putih kering mengandung $\beta$-glukan sebanyak 9,1 g/100 g. ${ }^{19}$ Sehingga dibutuhkan 1,21 $\mathrm{g} / \mathrm{kg}$ bb jamur tiram putih. Senyawa $\beta$-glukan tidak mengalami kerusakan akibat pemanasan dengan suhu $100^{\circ}$ selama 3 jam. $^{18}$ Sehingga diharapkan dengan adanya proses pemanasan senyawa $\beta$ glukan masih terkandung didalam sup jamur tiram putih. Metode pemberian jamur tiram putih yang dipilih dalam bentuk sup karena mudah diolah dan dikonsumsi. Selain itu, penambahan bawang putih dan lada pada pembutan sup juga dapat membantu dalam menurunkan kadar kolesterol total..$^{21,23}$ Diharapkan dengan pemberian sup jamur tiram putih dengan dosis $1,21 \mathrm{~g} / \mathrm{kg}$ bb/hari selama 21 hari dapat menurunkan kadar kolesterol total.

Pengambilan subjek penelitian dilakukan diwilayah Keluruhan Meteseh Semarang karena termasuk wilayah urban dimana kejadian obesitas, kadar kolesterol total batas atas dan kadar kolesterol total batas tinggi pada wilayah urban hampir sama dengan wilayah pusat kota. Subjek penelitian adalah guru dan karyawan dipilih karena memiliki aktifitas fisik yang rendah. Aktifitas fisik yang rendah merupakan faktor risiko yang dapat mengakibatkan dislipidemia. Selain itu, usia 40-50 tahun merupakan usia rawan terjadinya peningkatan kadar kolesterol total, obesitas dan sindroma metabolik. ${ }^{3,9}$

Berdasarkan uraian tersebut, maka peneliti ingin melakukan penelitian pengaruh pemberian sup jamur tiram putih (Pleurotus ostreatus) terhadap kadar kolesterol total pada subjek obesitas usia 40-50 tahun.

\section{METODE}

Penelitian ini merupakan pra eksperimen dengan rancangan pre test - post test design yang menggunakaan manusia sebagai manusia sebagai subjek penelitian. Variabel terikat (dependent variable) dalam penelitian ini adalah kadar kolesterol total. Varibel bebas (independent variable) adalah pemberian sup jamur tiram putih. Variabel perancu (confounding variable) adalah 
asupan makan berupa energi, kolesterol, asam lemak jenuh dan serat.

Perhitungan subjek penelitian menggunakan rumus uji hipotesis terhadap rerata sampel tunggal dan dibutuhkan sebanyak 10 subjek. Penentuan subjek penelitian menggunakan metode consecutive sampling. Subjek penelitian merupakan guru dan karyawan SMP negeri 33 Semarang. Kriteria inklusi penelitian ini adalah usia 40-50 tahun, memiliki kadar kolesterol total 200-239 mg/dl, lingkar pinggang di atas standar (laki-laki $\geq 90 \mathrm{~cm}$ dan wanita $\geq 80 \mathrm{~cm}$ ) menurut WHO untuk Asia Pasifik, tidak alergi maupun intoleran terhadap jamur tiram putih, tidak sedang mengonsumsi obat penurun kolesterol selama penelitian, tidak merokok, tidak dalam keadaan sakit atau dalam perawatan dokter berkaitan dengan penyakit jantung koroner, diabetes mellitus dan penyakit kronik lainnya dan bersedia mengikuti penelitian melalui persetujuan informed consent. Subjek dinyatakan keluar dari penelitian apabila tidak mengikuti prosedur penelitian, mengundurkan diri maupun meninggal dunia selama penelitian berlangsung.

Skrining awal melibatkan 72 guru dan karyawan SMP 33 Semarang, hasilnya terdapat 26 orang mengalami obesitas dilihat dari nilai IMT dan lingkar pinggang. Sebanyak 24 orang bersedia dilakukan pengambilan darah. Terdapat 19 orang subjek memenuhi kriteri inklusi. Selama penelitian 4 orang mengajukan pengunduran diri sebagai subjek penelitian ( 3 orang pelatihan diluar kota dan 1 orang merasa keberatan dengan penelitian). Sehingga terdapat 15 orang subjek ( 9 wanita dan 6 pria) yang mengikuti penelitian ini sampai selesai.

Pemberian sup jamur tiram putih dilakukan selama 21 hari. Cara membuat sup jamur tiram putih adalah jamur tiram putih sebanyak 1,21 gram/kgbb dicuci bersih dengan air mengalir. Kemudian dimasak dengan bumbu yang sudah dihaluskan yaitu bawang putih $0,2 \mathrm{mg} /$ gram jamur, lada $0,3 \mathrm{mg} / \mathrm{gram}$ jamur, dan garam $0,16 \mathrm{mg} / \mathrm{gram}$ jamur. Ditambahkan air sampai $50 \mathrm{ml}$ dan dimasak selama 5 menit.

Kadar kolesterol total dianalisis dengan menggunakan metode CHOD-PAP. Sampel darah diambil oleh petugas laboratorium setelah subjek berpuasa selama \pm 10 jam. Asupan makan seharihari pada subjek tidak dikontrol. Data asupan zat gizi selain asupan sup jamur tiram putih yang meliputi asupan energi, lemak jenuh, kolesterol dan serat diperoleh dari konsumsi makanan dan minuman subjek penelitian melalui wawancara sebelum dan selama intervensi menggunakan formulir food recall 24 jam. Data asupan makan subjek dianalisis menggunakan program nutrisurvey.

Pengukuran tingkat aktivitas fisik hanya diukur pada awal penelitian dengan menggunakan recall aktivitas 1x24 jam dengan menjumlahkan delta Physical Activity Level (PAL) untuk setiap aktivitas dalam 1 hari berdasarkan tabel aktivitas fisik dengan nilai Thermic Effect of Food (TEF) sebesar 1,1. Nilai PAL dibagi menjadi aktivitas fisik sedentary (1-1,39), rendah $(1,4-1,59)$, tinggi $(1,6-1,89)$ dan sangat tinggi $(1,9-2,5)$.

Uji normalitas data menggunakan uji Shapiro-Wilk karena sampel kurang dari 50. Analisis variabel perancu selama penelitian seperti asupan energi, kolesterol, lemak jenuh dan serat menggunakan uji korelasi. Perbedaan kadar kolesterol total sebelum dan sesudah intervensi diuji menggunakan uji wilcoxon dimana perbedaan dianggap bermakna apabila $\mathrm{p}<0,05$.

\section{HASIL PENELITIAN}

\section{Karakteristik Subjek Penelitian}

Karakteristik subjek yang terdiri dari usia dan status gizi disajikan dalam tabel 1.

Tabel 1. Karakteristik subjek

\begin{tabular}{lcccc}
\hline \multicolumn{1}{c}{ Variabel } & n & $\begin{array}{c}\text { Sebelum } \\
\text { intervensi }\end{array}$ & $\begin{array}{c}\text { Setelah } \\
\text { intervensi }\end{array}$ & $p$ \\
\hline Berat badan $(\mathrm{kg})$ & 15 & $70 \pm 9,44$ & $69,3 \pm 9,08$ & $0,009 *$ \\
Lingkar Pinggang $(\mathrm{cm})$ & & & & \\
$\quad$ Wanita $\geq 80$ & 9 & $87 \pm 5,56$ & $86 \pm 5,15$ & $0,169^{*}$ \\
$\quad$ Laki-laki $\geq 90$ & 6 & $95,7 \pm 3,55$ & $95,2 \pm 3,05$ & $0,043 *$
\end{tabular}

*Dependent t-test

Penyajian data berupa mean \pm standar deviasi (SD) dan jumlah subjek (n). Distribusi data diuji menggunakan uji Shapiro Wilk. Hasil dependent $\mathrm{t}$-test menunjukkan adanya perbedaan berat badan dan lingkar pinggang pria sebelum dengan setelah intervensi $(p<0,05)$. Sedangkan pada lingkar pinggang wanita tidak terdapat perbedaan sebelum dengan setelah intervensi ( $>0,05)$. Semua nilai PAL subjek dalam penelitian termasuk aktivitas rendah. 
Asupan energi, kolesterol, lemak jenuh dan serat

Asupan energi, kolesterol, lemak jenuh dan serat merupakan faktor-faktor yang dapat mempengaruhi kadar kolesterol total. Perbedaan rerata asupan makan 2 hari sebelum dan selama intervensi ditunjukkan pada tabel 2.

Tabel 2 menunjukkan bahwa asupan energi, kolesterol dan lemak jenuh sebelum intervensi lebih tinggi dibandingkan dengan selama intervensi. Rerata asupan serat sebelum intervensi lebih rendah 0,2 gram dibandingkan dengan selama intervensi. Persentase kecukupan asupan kolesterol dan lemak jenuh lebih dibandingkan dengan kebutuhan baik pada sebelum maupun selama intervensi. Persentase kecukupan asupan serat mengalami peningkatan selama intervensi dibanding dengan sebelum intervensi. Secara statistik asupan makan baik asupan energi, kolesterol, lemak jenuh maupun serat tidak terdapat perbedaan antara sebelum dengan selama intervensi $(p>0,05)$.

Uji korelasi variabel perancu menggunakan uji korelasi spearman karena data tidak berdistribusi normal untuk asupan kolesterol. Asupan energi, lemak jenuh dan serat menggunakan uji korelasi person. Hasil uji korelasi menunjukkan bahwa asupan energi, kolesterol, lemak jenuh dan serat tidak memiliki korelasi yang bermakna terhadap kadar kolesterol total $(\mathrm{p}>0,05)$. Nilai significant lebih dari 0,25 sehingga analisis multivariat tidak dapat dilakukan.

Tabel 2. Asupan energi, kolesterol, lemak jenuh dan serat

\begin{tabular}{|c|c|c|c|}
\hline \multirow[t]{2}{*}{ Asupan makan } & \multicolumn{2}{|c|}{ Subjek $(n=15)$} & \multirow{2}{*}{$\begin{array}{c}\% \\
\text { Kecukupan }\end{array}$} \\
\hline & Mean \pm SD & $\begin{array}{c}\text { Median } \\
(\min -\max )\end{array}$ & \\
\hline \multicolumn{4}{|l|}{ Energi } \\
\hline Awal & $1483,9 \pm 619,94$ & & $94,57 \%$ \\
\hline Intervensi & $1355,0 \pm 415,14$ & & $81,57 \%$ \\
\hline$p$ & $0,146^{*}$ & & \\
\hline \multicolumn{4}{|l|}{ Kolesterol } \\
\hline Awal & & $175,25(20,80-591,25)$ & $102,32 \%$ \\
\hline Intervensi & & $178,80(71,30-577,18)$ & $108,81 \%$ \\
\hline$p$ & & $0,910 * *$ & \\
\hline \multicolumn{4}{|l|}{ Lemak jenuh } \\
\hline Awal & & $25,85(6,45-33,25)$ & $110,07 \%$ \\
\hline Intervensi & & $19,00(11,36-37,85)$ & $115,22 \%$ \\
\hline$p$ & & $0,307 * *$ & \\
\hline \multicolumn{4}{|l|}{ Serat } \\
\hline Awal & $8,28 \pm 3,53$ & & $8,36 \%$ \\
\hline Intervensi & $8,48 \pm 3,42$ & & $42,44 \%$ \\
\hline$p$ & $0,794^{*}$ & & \\
\hline
\end{tabular}

Pengaruh konsumsi sup jamur tiram putih terhadap kadar kolesterol total

Uji beda yang digunakan adalah wilcoxon karena data kadar kolesterol total tidak berdistribusi normal. Hasil menunjukkan bahwa kadar kolesterol total mengalami penurunan dimana nilai media kadar kolesterol awal 226 $\mathrm{mg} / \mathrm{dl}$ dan median kadar kolesterol akhir 189 $\mathrm{mg} / \mathrm{dl}$. Terdapat perbedaan median kadar kolesterol total awal dan akhir penelitian yang signifikan dimana nilai $\mathrm{p} 0,001$.

Kepatuhan konsumsi sup jamur tiram putih

Selama penelitian sebanyak 4 orang dari 19 orang subjek hanya mengkonsumsi sup jamur tiram putih kurang dari 1 mingggu sehingga subjek dikeluarkan dari penelitian. Sebanyak 15 orang mengkonsumsi sup jamur tiram sampai habis selama penelitian.

\section{PEMBAHASAN}

Hasil penelitian menunjukkan bahwa pemberian sup jamur tiram putih dengan dosis $1,21 \mathrm{~g} / \mathrm{kg}$ bb selama 21 hari dapat menurunkan kadar kolesterol total pada subjek obesitas. Hal ini sesuai dengan hipotesis pada penelitian ini. Berdasarkan teori jamur tiram putih mengandung tinggi serat dan rendah lemak. Serat pangan yang terkandung didalam jamur tiram putih yang bersifat sebagai hipokolesterolemik adalah $\beta$ glukan. ${ }^{14}$ Penelitian mengenai efek antihiperkolesterol ekstrak alkali $\beta$-glukan jamur tiram putih pada hamster selama 2 minggu dapat 
memperbaiki kadar kolesterol total dan LDL secara signifikan dengan dosis $50,4 \mathrm{~g} / \mathrm{kg}$ bb atau setara dengan $0,11 \mathrm{~g} / \mathrm{kg}$ bb setelah dikonversikan untuk perhitungan pada manusia. ${ }^{18}$ Modifikasi diet rendah lemak yang direkomendasikan untuk menurunkan profil lipid dengan mengkonsumsi 25-40 gram serat makanan yang meliputi sedikitnya 7-13 gram serat larut selama 3 minggu. ${ }^{12}$ Jamur tiram putih mengandung $\beta$-glukan sebanyak 9,1 g/100 g. ${ }^{19}$ Pada penelitian ini dosis yang diberikan berkisar antara 7-9 gram $\beta$-glukan atau setara dengan 76-101 gram jamur tiram putih. Meskipun dosis terkecil 7 gram namun tetap memiliki pengaruh terhadap kadar kolesterol total.

Metode penggolahan jamur tiram putih berupa sup karena mudah diolah dan dikonsumsi. Sup jamur tiram putih menggunakan penambahan bawang putih dan lada pada pembutan sup juga dapat membantu dalam menurunkan kadar kolesterol total. ${ }^{21,23}$ Penelitian terdahulu yang dilakukan pada tikus sehat menunjukkan bahwa bawang putih dapat menurunkan kadar kolesterol total, glukosa darah, dan trigliserida secara signifikan selama 4 minggu dengan dosis 50 $\mathrm{mg} / \mathrm{kgbb}{ }^{20}$ Dosis bawang putih yangdianjurkan pada orang dewasa untuk menurunkan kadar kolesterol total sebanyak 4 gram atau (1-2 siung). Sedangkan dalam penelitian ini hanya menggunakan bawang putih sebanyak $0,2 \mathrm{mg} / \mathrm{g}$ jamur atau $<20 \mathrm{mg}$ perindividu.

Merica mengandung piperin yang dapat menurunkan kadar kolesterol total. Penelitian mengenai pengaruh suplementasi piperin dengan dosis $40 \mathrm{mg} / \mathrm{kgbb}$ pada tikus menunjukkan piperin dapat menurunkan kadar trigliserida, kolesterol total, dan LDL, serta meningkatkan kadar HDL tikus melalui mekanisme aktivitas tirogenik dimana terjadi pengaturan dalam kadar apolipoprotein dan resistensi insulin. Dosis piperin yang dianjurkan untuk orang dewasa sebesar 5-15 $\mathrm{mg} / \mathrm{hari}^{22,23}$ Merica yang ditambahkan kedalam sup jamur tiram putih jumlahnya lebih kecil yaitu < 30 gram per indivu dapat menurunkan kadar kolesterol total.

Kadar kolesterol total dipengaruhi oleh usia, status gizi obesitas dan asupan. Pada usia 4050 tahun memiliki metabolisme yang sama. Selain itu usia 40 hingga 50 tahun merupakan usia dimana kejadian sindroma metabolik mulai meningkat. ${ }^{19}$ Sebagian besar hiperkolesterolemia terjadi pada usia diatas 45 tahun. Peningkatan kolesterol total ini terjadi seiring dengan bertambanhnya usia. Hal tersebut tidak terjadi secara spontan tetapi lambat laun sejak masa kanak-kanak dan baru diketahui setelah memasuki umur 40 tahun ke atas. Mekanisme tersebut berhubungan dengan aktifitas reseptor LDL. Makin bertambah usia bersamaan dengan berkurangya aktifitas reseptor LDL. Hal ini menyebabkan banyak LDL yang tidak tertangkap oleh reseptor LDL sehingga LDL meningkat dan akan lebih lama berada dalam sirkulasi darah. Tingginya kolesterol dalam darah menunjukkan tingginya kolesterol total dalam darah, dimana kolesterol LDL dan kolesterol total mempunyai korelasi yang tinggi. ${ }^{24}$

Pria mempunyai risiko lebih tinggi terjadi hiperkolesterolemia dari pada wanita, hal ini dikarenakan hormon estrogen sebagai pelindung terjadinya plak pada pembuluh darah pada wanita lebih tinggi daripada pria. Tetapi mempunyai risiko sama besar pada pria maupun wanita pada usia 45-54 tahun..$^{25}$

Kenaikan berat badan yang terjadi secara terus menerus dan masuk kedalam kategori obesitas dapat menggangguan metabolisme lipid yang berupa peningkatan kadar kolesterol, trigliserida, kolesterol LDL dan penurunan kolesterol HDL. Penurunan berat badan dapat memperbaiki profil lipid. Setiap penurunan $1 \mathrm{~kg}$ berat badan berhubungan dengan penurunan sekitar 3\% trigliserida dan kenaikkan 1\% HDL. $^{2}$ Dalam penelitian ini terjadi perbedaan rerata berat badan antara sebelum dengan setelah intervensi. Sebanyak 11 subjek mengalami penurunan berat badan. Penurunan berat badan yang terjadi berkisar anatara 0,9-2,3 kg. Penurunan berat badan mungkin disebabkan karena peningkatan aktivitas fisik dan kandungan serat pangan dalam sup jamur tiram putih. Aktivitas fisik yang rendah akan mendorong keseimbangan energi ke arah positif sehingga mengarah pada penyimpanan energi dan penambahan berat badan, hal ini akan berakibat pada peningkatan kadar koleterol total. ${ }^{28}$ Namun, dalam penelitian ini tidak dilakukan pengujian terhadapan aktivitas fisik subjek selama penelitian berlangsung. Serat pangan $\beta$-glukan yang terkandung dalam sup jamur tiram putih merupakan serat larut yang dapat menunda pengosongan lambung menyebabkan penurunan penyerapan nutrisi dilambung. Hal tersebut dapat meningkatkan rasa kenyang yang lebih lama berhubungan dengan penurunan berat badan. ${ }^{14,26}$

Asupan merupakan faktor penting yang mempengaruhi kadar lipid terutama pada orang obesitas. Orang obesitas cenderung mengalami kelebihan konsumsi energi, lemak jenuh dan kolesterol namun rendah serat. Konsumsi makanan sumber lemak jenuh dan kolesterol dalam jumlah yang tinggi secara terus menerus dipercaya 
mempengaruhi secara langsung profil lipid plasma, hiperkolesterolemia dan aterosklerosis. ${ }^{7}$ Asupan lemak jenuh lebih memiliki efek signifikan dalam menaikkan kadar kolesterol total dan kolesterol LDL dibandingkan dengan asupan kolesterol. Lemak jenuh menaikkan kadar kolesterol LDL dengan cara menurunkan sintesis dan aktifitas reseptor LDL. ${ }^{26}$ Pengurangan asupan lemak dan mengganti lemak jenuh dan lemak trans dengan lemak tak jenuh, pembatasan asupan kolesterol dan peningkatan asupan serat dapat menurunkan kadar kolesterol total, kolesterol LDL dan trigliserida. Pengurangan asupan lemak tak jenuh sampai 7\% dari total kalori dan pembatasan kolesterol sampai $200 \mathrm{mg}$ per hari dapat menurunkan 9-12\% kadar kolesterol LDL. ${ }^{27}$ Modifikasi diet rendah lemak yang direkomendasikan adalah dengan mengkonsumsi 25-40 gram serat makanan yang meliputi sedikitnya 7-13 gram serat larut selama 3 minggu. ${ }^{12}$

Pada penelitian ini secara menyeluruh asupan makan seperti energi, kolesterol, lemak jenuh dan serat tidak mengalami perbedaan antara sebelum dengan selama intervensi. Hal ini menunjukkan bahwa asupan makan tidak mempengaruhi penurunan kadar kolesterol total. Dapat disimpulkan bahwa sup jamur tiram putih tanpa diikuti dengan perubahan asupan (penurunan asupan energi, kolesterol, lemak jenuh dan peningkatan serat) selama intervensi dapat menurunkan kadar kolesterol total pada subjek obesitas. Namun pada penelitian ini terdapat beberapa subjek yang kadar kolesterol total dipengaruhi oleh asupan.

Pada penelitian ini terdapat 2 subjek yang mengalami kenaikan kolesterol total. Subjek pertama mengalami kenaikan sebanyak $5 \mathrm{mg} / \mathrm{dl}$, sedangkan subjek kedua mengalami kenaikan sebanyak $2 \mathrm{mg} / \mathrm{dl}$. Pada subjek pertama meskipun rerata asupan energi dan kolesterol mengalami penurunan selama intervensi namun rerata asupan lemak jenuh mengalami peningkatan sebanyak 2,95 g dan rerata asupan serat mengalami penurunan sebanyak $0,15 \mathrm{~g}$. Subjek kedua rerata asupan kolesterol mengalami penurunan selama intervensi dan rerata asupan serat meningkat 0,31 $\mathrm{g}$, tetapi rerata asupan energi meningkat $66,10 \mathrm{kkal}$ dan lemak jenuh 5,23 g. Pada kedua subjek ini menunjukkan bahwa peningkatan asupan lemak jenuh, energi dan penurunan asupan serat dapat menaikkan kadar kolesterol total meskipun terapi sup jamur tiram putih telah diberikan.

Sebanyak 4 subjek mengalami penurunan koleseterol total tetapi masih dalam kategori batas atas. Subjek pertama mengalami penurunan kolesterol total sebanyak $10 \mathrm{mg} / \mathrm{dl}$, subjek kedua menurun $15 \mathrm{mg} / \mathrm{dl}$, subjek ketiga menurun 11 $\mathrm{mg} / \mathrm{dl}$ dan subjek keempat $10 \mathrm{mg} / \mathrm{dl}$. Subjek pertama mengalami peningktan rerata asupan energi 10,35 kkal dan lemak jenuh 5,45 g, penurunan rerata asupan kolesterol 71,04 $\mathrm{mg}$ dan serat $1,8 \mathrm{~g}$. Subjek kedua mengalami penurunan rerata asupan energi 320,29 kkal dan serat $1,71 \mathrm{~g}$, namun mengalami peningkatan pada rerata asupan lemak jenuh 12,55 g dan kolesterol 114,43 mg. Subjek ketiga mengalami penurunan rerata asupan energi $101,1 \mathrm{kkal}$, peningkatan rerata asupan kolesterol 310,68 mg, serat 4,49 g, lemak jenuh 0,43 g. Ketiga subjek ini menunjukkan bahwa asupan kolesterol dan lemak jenuh berpengaruh terhadap masih tingginya kadar kolesterol total. Subjek keempat meskipun asupan energi basal tidak terpenuhi baik sebelum maupun selama intervensi kadar kolesterol termasuk dalam kategori batas tinggi. Hal ini mungkin dikarenakan subjek terbiasa mengkonsumsi sumber asam lemak jenuh dan kolesterol seperti santan dan gorengan. Selain itu, subjek juga mengalami peningkatan asupan lemak jenuh dan penurunan asupan serat selama intervensi.

Salah satu subjek mengalami penurunan kadar kolesterol total yang drastis yaitu terjadi penurunan sebanyak $90 \mathrm{mg} / \mathrm{dl}$. Hal ini dikarenakan subjek ini membatasi asupan makanan secara drastis selama intervensi berlangsung. Subjek yang mengetahui kadar kolesterol total termasuk dalam kategori batas tinggi sebelum intervensi dilakukan memutuskan untuk membatasi asupan makan hingga energi basal tidak terpenuhi.

Serat pangan $\beta$-glukan yang merupakan serat larut berperan dalam penurunan kadar kolesterol total. Serat larut dapat meningkatkan masa feses dan sebagai agen penurunan kolesterol. $^{12}$ Mekanisme penurunkan kadar kolesterol oleh serat adalah (a) peningkatan ekresi asam empedu dan kolesterol pada feses. Penurunan asam empedu yang kembali ke hati dan penurunan absorpsi kolesterol menyebabkan penurunan kandungan kolesterol pada sel hati. Penurunan kolesterol hati menyebabkan pemindahan kolesterol LDL dari darah. Penurunan asam empedu yang kembali ke hati mengharuskan penggunaan kolesterol untuk mensintesis asam empedu baru. Hal ini dapat menurunkan kadar kolesterol ; (b) perpindahan asam empedu dalam bentuk asam kolik dan asam kenodoksikolik. Asam kenodoksikolik muncul sebagai penghambat HMG CoA reduktase yang merupakan enzim regulator yang dibutuhkan dalam proses sintesi kolesterol ; (c) produksi propionat atau asam 
lemak rantai pendek lain akibat degrasi serat oleh bakteri. Penurunan kadar kolesterol yang terjadi sebagai akibat propionat menghambat sintesis asam lemak. ${ }^{25}$

\section{SIMPULAN}

Pemberian sup jamur tiram putih dengan dosis $1,21 \mathrm{~g}$ per kilogram berat badan per hari selama 21 hari secara signifikan berpengaruh terhadap kadar kolesterol total pada subjek obesitas.

\section{SARAN}

Diperlukan uji laboratorium untuk mengetahui kandungan beta glukan di dalam sup jamur tiram putih. Bagi subjek yang memiliki kadar kolesterol total batas atas dapat mengkonsumsi sup jamur tiram putih 1,21 $\mathrm{g} / \mathrm{kgbb} / \mathrm{hari}$ sebagai alternatif asupan serat larut untuk menurunkan kadar kolesterol total. Diperlukan penelitian lebih lanjut mengenai asupan sup jamur tiram putih dan aktivitas fisik terhadap kadar kolesterol total.

\section{DAFTAR PUSTAKA}

1. Singh AK, Singh SK, Singh N, Agrawal N, Gopal $\mathrm{K}$. Obesity and dyslipidemia. International Journal of Biological and Mendical Research 2011; 2(3): 824-828

2. Nammi S, Koka S, Chinnala KM, Boini KM. Obesity: An overview on its current perpectives and treatment options. Nutrition Journal 2004, 3:3

3. Kementerian Kesehatan RI. Riset Kesehatan Dasar. 2013: 224

4. Suprihatin SH, Eriza F, Dian RK. Hubungan lingkar pinggang dengan kadar trigliserida pada pasien rawat jalan dislipidemia di puskesmas janti kota Malang. Universitas Brawija. 2013

5. Fauci, Braunwald, Kasper, Hauser, Longo, Jameso, et, al. Harrison's Principle of internal medicine. 17th ed. 2008

6. Executive summary of the third report of the National Cholesterol Education Program (NCEP) expert panelon detection, evaluation, and treatment of high blood cholesterol in adults (Adult Treatment Panel III). JAMA.2001

7. Otunola GA, Oyelola BO, Adenike TO, Anton AA. Effest of diet-induced hypercholesterolemia on the lipid profil and some enzyme activities in female wistar rats. African Journal of Biochemical Research 2010; 4(6): 149-154

8. Kathleen MB, Mayes PA. Sintetis, Transport dan Ekskresi Kolesterol. In: Murray RK, Granner DK, Mayes PA, Rodwell VW, editors. Biokimia Harper. Edisi 27. Jakarta: Penerbit Buku Kedokteran EGC; 2009.p.239-2

9. Park HS, Sang WO, Sung-il O, Woong HC, Young SK. Cardiovascular Disease and Diabetes : The metabolic syndrome and associated lifestyle factors among South Korean adults. International Journal of Epidemiology 2004;33(2):328-336

10. Stapleton PA, Adam GG, Milinda EJ, Robert WB, Jefferson CF. Hypercholesterolemia and microvascular dysfunction: interventional strategies. Journal of Inflammation 2010, 7:54

11. Gardjito, Fajar Baskoro. Korelasi kolesterol-HDL dengan IMT pada penderita jantung koroner di RSUD Moewardi Surakarta. Universitas Sebelas Maret. 2009

12. Reiner Z, Alberico LG,Guy De, Ian G, Marja-Riita $\mathrm{T}$, Olov Wiklund, et al. ESC/EAS Guildeline for the management of dyslipidemia. The task force for the management of dyslipidemias of the European Society of Cardiology (ESC) and the European Atherosclerosis Society (EAS). European Heart Journal 2011; 32

13. Schneider I, Gaby K, Annette M, Ulrich K, Ralf GB. Lipid lowering effects of oyster mushroom (Pleurotus ostreatus) in human. Journal of Functional Food 2011;3:17-24

14. Setyasih M, Sri A. Kandungan kolesterol serum dan sifat digesta tikus sprague dawley hiperkolesterolemia yang diberi pakan jamur tiram putih (Pleuritus ostreatus) olahan. Universitas Gadjah Mada 2013

15. Salas-Salvadó J, Mónica B, Ana P, Emilio R. Dietary fibre, nuts and cardiovascular disease. British Journal of Nutrition 2006;96 (Suppl 2): S45-S51

16. Alarcón J, Osacar F, Enrique Z. Production and purification of statins from pleurotus ostreatus (basidiomycetes) strains. Znaturforsch 2003

17. Lakshmanan D, Radha KV. Production of lovastatin from Pleurotus ostreatus and comparison with commercial tablets. International Journal of Pharmacy and Pharmaceutical Science Research 2012; 2(3): 53-56

18. Santoso F, Priyo W, Elly Wardani. Uji aktivitas antihiperkolesterol ekstak $\beta$-glukan larut alkali jamur tiram putih (Pleurotus ostreastus (Jacq.) P.Kumm) pada hamster hiperkolesterolemia. Universitas Muhammadiyah Prof. Dr. Hamka 2012

19. Mölleken H, Jörg N, Hendrik M, Tim M, Hans JA. A new calorimetric method to quantify $\beta-1,3-1,6-$ glucons in comparasion with total $\beta$-1,3-glucans and a method to quantify chitin in edible mushrooms. International Conference on Mushroom Biologyand Mushroom Products 2011

20. Martha Thomson, 4 Khaled K. Al-Qattan, Tanuja Bordia, and Muslim Ali. Including Garlic in the Diet May Help Lower Blood Glucose, Cholesterol, and Triglycerides. Journal of Nutrition. 2006

21. Karin Ried, Catherine Toben, and Peter Fakler. Effect of garlic on serum lipids: an updated metaanalysis. Nutrition Review. 18 Maret 2013

22. Vijayakumar RS, Nalini N. An active principle from Piper nigrum, modulates hormonal and apo 
lipoprotein profiles in hyperlipidemic rats. J Basic Clin Physiol Pharmacol. 2006;17(2):71-86

23. Shreya SS, Gaurang BS, Satbeer DS, Priyanshi VG, Kajal C, Khyati AS, et,al. Effect of piperine in the regulation of obesity-induced dyslipidemia in high-fat diet rats. indian J Pharmacol. 2011 MayJun; 43(3): 296-299.

24. Bintanah SM. Hubungan konsumsi lemak dengan kejadian hiperkolesterolemia pada pasien rawat jalan di poliklinik jantung rumah sakit umum daerah Kraton kabupaten Pekalongan. J Kesehat Masy Indonesia. 2010:6(1)

25. Nadkarni S, Dianne C, Vincenzo B, Stefania B, Mauro P. Activation of the annexin A1 pathway underlies the protect effects exerted by estrogen in polymorphonuclear leukocytes. Arterioscler Thromb Vasc Biol. 2011;31: 2749-2759

26. Sareen SG, Jack LS, James LG. Advanced Nutrition and Human Metabolism. $5^{\text {th }}$ edition. Canada:Wadsworth Cengage Learning; 2009

27. Kelly RB. Diet and exercise in the management of hiperlipidemia. American Family Physician 2010; 81(9): 1097-1102

28. Waloya T, Rimbawan, Nuri W. Hubungan antara konsumsi pangan dan aktivitas fisik dengan kadar kolesterol darah pria dan wanita dewasa di Bogor. Jurnal Gizi dan Pangan. 2013 